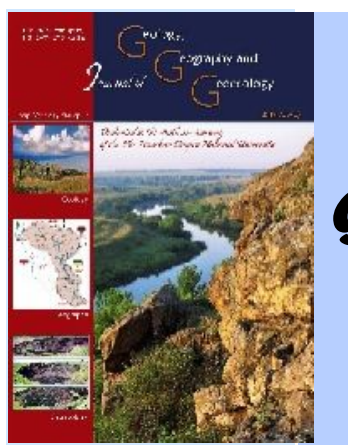

O. V. Havriushyn.

\section{Journal of Geology.} Geography and Geoecology

\author{
Journal home page: geology-dnu-dp.ua
}

Journ.Geol.Geograph.

Geoecology,

27(2), 213-221

doi: $10.15421 / 111846$

Journ.Geol.Geograph.Geoecology, 27(2), 213-221

\title{
Mapping the spatial and temporal distribution of changes in the administrative-territorial division
}

\author{
O. V. Havriushyn
}

Oles Honchar Dnipro National University, Dnipro,Ukraine, e-mail: audi@email.ua

Received 30.07.2018;

Received in revised form 09.08.2018;

Accepted 04.10.2018

\begin{abstract}
The article is devoted to the development of the content of generalized maps on the history of administrative-territorial division. The purpose of such maps is to reflect the features of the space-time distribution of administrative changes. We have found that it is better to link indicators of dynamics to such spatial objects as the territories of modern administrative-territorial units (or the territory of historical administrative-territorial
\end{abstract} ones as of a certain date), to polygons of a single history of administrative membership, to administrative-territorial units as dynamic objects.Under the polygons of a single history of administrative ownership, we mean the territories identified during the analysis, all points within which belonged to the same administrative-territorial unit at any time during the analyzed period. Unlike polygons of the smallest common geometry (used in the method of space-time composites), such objects can be allocated for different periods of time and for different administrative levels.For such spatial objects, we propose to calculate and display on the map the number of changes in administrative ownership or the total duration of belonging to some administrative-territorial unit (usually, a high level). For larger static areas than the polygons of a single history of administrative affiliation, we suggest calculating and displaying on the map the indicator of administrative variability and the average duration of ownership. In our opinion, the indicator of administrative variability should consider the size of the analyzed territory, the number and volume of spatial changes. We have developed a formula for calculating such an indicator.The indicators that we calculate for historical administrative-territorial units on the map are displayed within the static contour. However, these indicators are calculated for a dynamic object. These indicators are: the number of changes, the total number of changes in parameters, the total number of dates of change, the spatial configuration variability index, the area-weighted average area and its relation to the modern one. We propose to calculate the index of the variability of the configuration of the administrative-territorial unit as the sum of the relations of the areas of the reassigned territories to the areas of the administrative-territorial unit at the time before the change. Since different administrative-territorial units have different duration of existence, in our opinion, it is important to analyze not only the quantity but also the intensity of the changes. To reflect on the map the course of changes in the administrative-territorial unit in time, we developed a timeline-based chart.

Key words: administrative-territorial division, mapping, timelines, generalization of time-varying data, spatial and temporal distribution of changes

\section{ртогр фув ння просторово-ч сового розподілу змін дміністр тивно-територі льного поділу}

\author{
. . врюшин
}

ніпровський н ціон льний університет імені леся онч, ніпро, кр їн, е-таil: audi@email.ua

нот ція. иявлено, що пок зники дин міки доцільно прив'яз ти до т ких просторових об'єктів як території суч сних дміністр тивно-територі льних одиниць ( бо територій історичних дміністр тивно-територі льних одиниць ст ном н певну д ту), полігони єдиної історії дміністр тивної прин лежності, дміністр тивно-територі льних одиниць як дин мічних об’єктів. ля полігонів єдиної історії дміністр тивної н лежності пропонуємо розр ховув ти т відобр ж ти н к рті кількість змін дміністр тивної н лежності бо сум рної трив лості н лежності до певної дміністр тивно-територі льної одиниці. ля більших ст тичних територій, ніж полігони єдиної історії дміністр тивної прин лежності, пропонуємо розр ховув ти т відобр ж ти н к рті пок зник дміністр тивної мінливості т середньої трив лості н лежності. ок зник дміністр тивної мінливості повинен вр ховув ти розміри н лізов ної території, кількість т обсяги просторових змін. озроблено формулу розр хунку т кого пок зник. ок зники, які ми розр ховуємо для історичних дміністр тивнотериторі льних одиниць, н к рті відобр ж ються в меж х ст тичних контурів. дн к ці пок зники в дійсності розр хов ні для дин мічного об’єкт . кими пок зник ми є: кількість змін конкретного виду, з г льн кількість змін п р метрів, з г льн кількість д т змін, пок зник мінливості простору, середньозв жен в ч сі площ і її відношення до суч сної. ропону- 
ємо розр ховув ти пок зник мінливості конфігур ції дміністр тивно-територі льної одиниці як суму відношень площ перепідпорядков них територій до площ н м момент до зміни. бгрунтов но доцільність н лізу крім кількості змін їх інтенсивності. ля відобр ження н к рті змін дміністр тивно-територі льної одиниці в ч сі розроблено ді гр му н основі т ймл йну.

лючові слов : дміністр тивно-територі льний поділ, к ртогр фув ння, $m$ ймл йни, уз г льнення різноч сових д них, просторово-ч совий розподіл змін

Introduction. In independent Ukraine, the interest to the topic of administrative-territorial division (ATD) in general and history of its development in particular increases. A scientific discussion of reforming the current administrative division goes on in the country. However, in retrospective studies on the administrative division of Ukraine, the cartographic method of study and modern geoinformation techonogies were not used broadly. The maps of the history of the administrative division are available in many history atlases, and also in particular scientific works (Trotsenko, 2008). Nonetheless, in content, they are mostly combinations of the borders in different periods on a single map or the maps which demonstrate the course of administrative changes over a short period of time. At the same time, there are no generalized maps which would reflect the pe-culiarities of spatio-temporal division of changes over a long period demonstrating the differences in the administrative history of different objects (territories).

In foreign countries, the aspects of cartography of the spatio-temporal division of the administrative changes are also insufficiently developed . Some cartographic works demonstrate the changes in the situation using special graphic models, for example the timelines in the GeaCron Atlas (this is not on the map, but presented as additional information), theoretical aspects of developing such graphic models for political territorial objects were studied by A. Renolen. More developed are the issues of the history of administrative division (or political map) in the GIS data bases and their visualizations, and also general issues of the data analysis related to the ad-ministrative-territorial units variable over time. Especially notable are the studies by I.Gregory. M. Berman, M. DeMoor, T. Wiedemann, M. Nüssli, C. Nüssli, E. VanHaute and also the studies conducted earlier and general theoretic studies on the presentation and analysis of historical data in GIS, particularly Langran (1992).Some developments in the sphere of presenting data can be used and for visualizing the spatio-temporal distribution of changes. E. VanHaute considers one of the advantages of describing changes in ATD using the method of "least common geometry" (LCG), also known as "space- time composite"or"spatiotemporalcomposite"(STC) to be the opportunity of using LCG polygons for studying the changes in the attributive data over time (VanHaute, 2005). That is, the LCG polygons are considered not only as the units of data maintanence for the next aggregation and depiction of the administrative units of higher levels, but as the spatial basis for the attributive data and their visualizations.

The goal of the study was to develop a content (objects of mapping, parameters) and graphic tools for creating maps which demonstrate the peculiarities of spatial and spatio-temporal division of administrative changes and duration of the administrative belonging.

Materials and methods. The study is methodological and was made on cartographic and text materials on the history of administrative-territorial division of Dnipropetrovsk Oblast. During the development of the approaches for mapping the spatiotemporal division of administrative changes, we followed the idea of division of the administrativeterritorial units into smaller polygons, which lays in the basis of the method of spatio-temporal composites and the method of visualizing the course of events in time, known as timeline.

Results and their analysis. The parameters which characterize the level of ATD dynamic can have different spatial localization and be calculated for static polygon objects, for dynamic polygonal objects, linear objects, points of regular network, etc. (Havriushyn, 2018).

As static polygonal objects, we can consider the territories located within administrative borders. They can correspond to the administrativeterritorial unit (ATU) either at a certain date or be a result of generalized borders of ATU over different periods of time.

Among static polygonal objects created as a result of generalizing the borders of an ATU over different time periods, special significance belongs to the polygons of the common history of administrative belonging $(\mathrm{CHAB})$ - a territory, all points of which belong to the same historical ATU in every moment of the period of study.

Dynamic polygonal objects are historic ATU in time dimension (Table 1) 
Table 1. The objects of cartography and the parameters on the maps of spatio-temporal division of changes in ATU

\begin{tabular}{|l|l|l|l|}
\hline \multirow{2}{*}{} & \multicolumn{3}{|c|}{ Objects of mapping } \\
\cline { 2 - 4 } & ATU in variable borders & $\begin{array}{l}\text { Territory of current ATU } \\
\text { (as at) }\end{array}$ & Polygons of CHAB \\
\hline Map purpose & $\begin{array}{l}\text { Visualizing of the indi- } \\
\text { vidual peculiarities of } \\
\text { history of different his- } \\
\text { toric ATU }\end{array}$ & $\begin{array}{l}\text { Demonstrating changea- } \\
\text { bility of the administra- } \\
\text { tive belonging of the terri- } \\
\text { tory within the borders of } \\
\text { current ATU or historic } \\
\text { belonging recorded for a } \\
\text { particular date }\end{array}$ & $\begin{array}{l}\text { Demonstrating distribution of } \\
\text { the number of changes and } \\
\text { lunging in the area }\end{array}$ \\
\hline $\begin{array}{l}\text { Parameters } \\
\text { racteristics) } \\
\text { of the object }\end{array}$ & $\begin{array}{l}\text { Duration and chronolog- } \\
\text { ic frames of existence, } \\
\text { area, type, name, admin- } \\
\text { istrative centre }\end{array}$ & $\begin{array}{l}\text { Parameter of administra- } \\
\text { tive belonging }\end{array}$ & $\begin{array}{l}\text { Total number of associations, } \\
\text { total number of ATUs they } \\
\text { belonged to, duration of be- } \\
\text { longing to ATUs }\end{array}$ \\
\hline
\end{tabular}

Polygons of CHAB (Fig. 1) are the most suitable for mapping the division of the number of changes in administrative belonging (reassociations) or duration of belonging to a certain object (ATU). Maps of number of re-associations (or num-ber of ATUs the territory belonged to) by polygons of $\mathrm{CHAB}$ enable depiction of spatial division of administrative changes and determination of territories more or less stable in administrative context. Maps of long belonging of territory to ATU by polygons of $\mathrm{CHAB}$ demonstrate peculiarities of formation of borders of ATU, particularly allow distinguishing the "historical kernel" - a territory which always remained within a studied object and borders of territory ever included in the ATU.

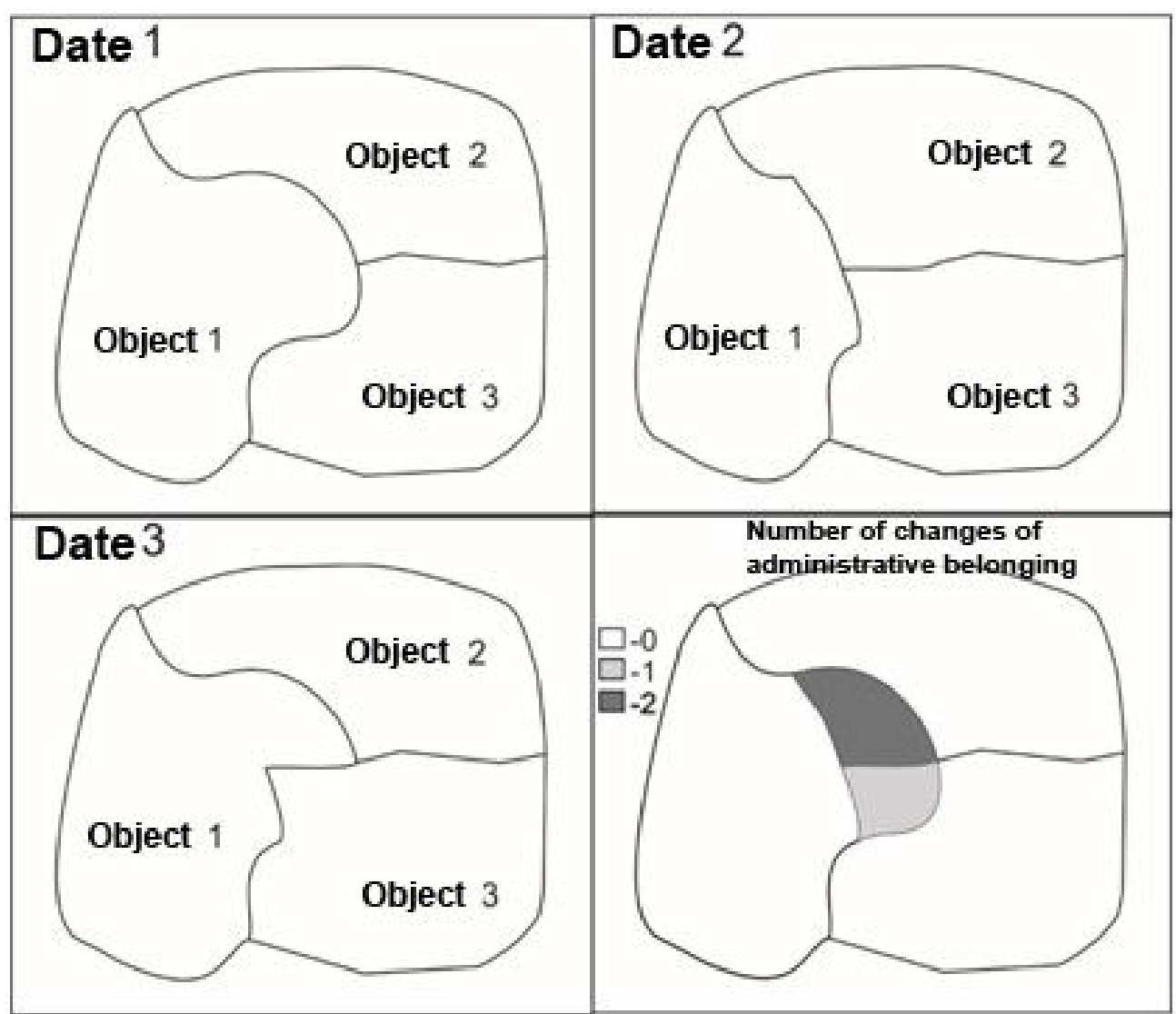

Fig. 1. Distinguishing polygons of common history of administrative belonging and visualization of the number of administrative changes 
To automatise the process of creating polygons of CHAB in GIS for ATD history, we created a program module using Mapbasic language. The algorithm of creating CHAB polygons is as follows. The program selects polygons which represent the contours of the ATU described by the user (or of the entire region or all ATUs - depending on the purpose), converts them to polylines and unites into a single object. Then, using a "polygonsclose" function, CHAB polygons should be created between the lines of administrative borders.

Such algorithm was also used in other GIS on the condition that their bases contain ATU polygons created already. If a base contains LCGpolygons, using which ATU polygons for different dates can be created, these polygons can be used. However, if the period of study on the changes is shorter than the one covered in GIS, mapping of changes by LCG-polygons will lead to excessive fragmentation of space. Therefore, the territories which really did not differ in their history of administrative belonging over an analyzed period will be divided by borders. This is explained by the fact that differences occurred in other periods, and this is reflected in LCG polygons which are distinguished during the entire period, in contrast to $\mathrm{CHAB}$ polygons which are distinguished in a particular context. Therefore, it is best to enlarge the net from LCG to CHAB polygons.

In some cases, the alternative of CHAB polygons for mapping the division of the number of administrative re-associations can be the points of regular network or creating isolines on their bases, although $\mathrm{CHAB}$ polygons, due to the fact that they are formed by fragments of historical administrative borders which really existed, reflect the borders of areas with different number of changes most accurately, unlike regular network of isolines or raster palettes created using the points.

The algorithm of calculation of the number of re-associations, number of objects, CHAB polygon belonged to, or duration of long belonging depends on the spatio-temporal database, on the basis of which the mapping is conducted. In GIS database, ATD of Dnipropetrovsk Oblast contained ATU polygons created for different dates. Polygons which reflect the same ATU have a common code. Therefore, the algorithm of calculation of number of re-associations is as follows. Out of the ATU layer, ATUs are selected for each CHAB polygon, which contain this polygon (using SQL-requests with ContainsorWithin operators). Countoperator calculates the number of records and subtracts 1 from the obtained value. If at the same time, one unites the ATU records by code and uses Count operator for the obtained selection, instead of the number of re-associations, one will obtain the num- ber of ATUs the CHAB polygon belonged to. For calculating duration of a $\mathrm{CHAB}$ polygon belonging to a selected ATU, one should select all polygons which contain this CHAB polygon, and sum the difference of "Date_final" and "Date_initial" lines for each of the records.

Sizes of CHAB polygons are usually small compared to an ATU and significantly vary, their number on the map can reach several dozens (depending on size of the studied territory and period of study). Significant differences are possible also in the value of the parameters which are being mapped. Therefore, for visualization at automised creation of maps using GIS, it is best to use a special sample "ranges" between diagrams with absolute scale.

Division of temporal administrative belonging and duration of belonging of a territory to certain objects can be determined also by static objects larger by $\mathrm{CHAB}$ polygons. In our opinion, the relevant issue is developing maps which would show peculiarities of ATD history within current ATUs. However, the total number of re-associations for these spatial objects, in contrast to $\mathrm{CHAB}$ polygons is not representative insofar as at a particular date, it is not an entire object that is being re-associated, but only a part of its territory.

Therefore, there was developed a special parameter of temporality of administrative belonging of a territory, which takes into account the number of territorial changes within an ATU, the area of these changes and the area of the ATU territory. Because any ATU territory with an area of S can be divided into $\mathrm{n} C \mathrm{CHAB}$ polygons with $\mathrm{s}_{1} . . \mathrm{s}_{\mathrm{n}}$ areas, each of which is characterized by a certain number of $p_{1} . . p_{n}$ re-associations, the parameter of administrative temporality can be calculated as a ratio of the sum of the products of multiplying the $\mathrm{CHAB}$ polygon areas $\left(\mathrm{s}_{\mathrm{i}}\right)$ (within the ATU) by the number of re-associations $\left(\mathrm{p}_{\mathrm{i}}\right)$ they underwent to the total area of ATU (S).

$$
m=\frac{\sum_{i=1}^{n} p_{i} * s_{i}}{s}
$$

The numerator in the fraction of the formula (1) is the total area of all re-associated territories which were located within ATU territory during different time periods. This parameter has an individual value, although, taking into account different areas of ATU, to compare the temporality of administrative belonging, it is better to use parameter $\mathrm{m}$.

Taking into account that each CHAB polygon is characterized by individual duration of belonging to an ATU $\left(t_{i}\right)$, the averaged parameter (mean value) of the duration of belonging can be determined for a particular date (current condition) 
within its contour. This can be an absolute indicator - number of years over which on average its territory belonged to the object (2), and relative indicator - ratio of the years over which on average its territory belonged to the object to the duration of the object's existence.

$$
T=\frac{\sum_{i=1}^{n} t_{i} * s_{i}}{s}
$$

Research on the dynamics of ATD by fixed polygonal contours does not cover many aspects related to the peculiarities of historical changes of ATUs as dynamic objects. Therefore, the parameter of administrative temporality within an administrative district characterizes this territory, but not the dynamic of the ATU itself, the borders of which changed and did not match the current ones, and the time of existence can be much shorter than the period for which the value is calculated. Also, an ATU have non-positional (attributive) characteristics, the changes of which also should be studied.

Therefore, it is practical to develop a series of maps which would reflect the peculiarities of the history of the ATUs (as dynamic objects) in different periods. These periods are distinguished individually for the history of the ATU of a certain period. On such maps, it is possible to show administrative borders at a particular date, or borders of the ATU for different dates (for example, borders of each ATU in minimal sizes - to cover more historical objects) and visualize particular indicators of historical ATUs within the depicted borders.

Because the parameters of historical ATUs on the maps are calculated for dynamic objects, and are depicted within fixed contours, such maps cannot be considered as those which should be made using the tools of cartography and diagrammatic maps, at least in the classic sense.

The dynamic of an ATU, in our opinion, can be expressed using the following parameters: number of changes of particular type, total number of changes in parameters, total number of dates of changes, parameters of temporality of the spatial configuration, average area in time and its ratio to the current area.

Let us analyze in more detail the parameter of temporality of spatial ATU configurations. Similarly to the parameter of temporality of administrative belonging of a territory with fixed borders $\mathrm{m}$, this indicator should cover the number of territorial changes the object underwent, the extent of these changes and area of the object. However, in this case, the area of an object is variable. Therefore, we suggest calculating the parameter of temporality of
ATU configuration as a sum of ratios of the reassociated territory to the area of ATU at the moment of change.

For ATUs as objects which have different duration of existence, it is relevant also to calculate not only the parameters of the number of changes, but also their intensity. Such parameters can be deter-mined by dividing the parameter of number of changes by the duration of the ATU's existence.

The approaches described above allow demonstration of the peculiarities of spatial division of changes or duration of the belonging, but not the course of these changes over time (if not taking into account the possibility of developing a series of maps - for different periods).

To show the peculiarities of temporal division, one can use special diagrams on the basis of timeline.

Such diagrams can indicate:

time over which (when) the first long period of changes took place (change);

qualitative characteristic of the object; quantitative characteristic of the object.

Comparison of the maps indicating the course of changes in an ATU over time and total number of changes is demonstrated in Table 2 .

Duration of a certain process can be demonstrated by a section (sections) of horizontal line parallel to the time scale with corresponding length and position in relation to scale. Dates of changes (events) can be demonstrated with special indicators on the time scale or in "tracks" parallel to it.

Except the horizontal scale, quantitative changes can be demonstrated using the vertical scale. As an alternative, one can develop a graduated scale and demonstrate the value by thickness of the line (for long process) or size of the intersections (for instant change).

Because the change in area of an ATU involves either loss or gain of territory, the graph of change in the territory does not always demonstrate the extent of spatial changes adequately. In some cases, if lost or affiliated territories are insignificantly different in area, the ultimate area of the object undergoes the least changes while having significant changes of its spatial configuration. Therefore, to demonstrate the extent of spatial changes, it is best to show not the general area, but the area re-associated at different dates, or both parameters.

Qualitative characteristics can be divided into individual and those which are used for all objects from a short list. Individual parameters are the ATU's name, its administrative centre. The other parameters include type of ATU. It can be demonstrated using colours for its "lines of existence". 
Table 2. Parameters of historical ATUs which are being mapped

\begin{tabular}{|l|l|l|}
\hline Characteristics of ATU & $\begin{array}{l}\text { Parameters which depict course of } \\
\text { changes over time }\end{array}$ & $\begin{array}{l}\text { Parameters indicated in maps, which } \\
\text { demonstrate only spatial division of } \\
\text { number of changes }\end{array}$ \\
\hline Characteristics of time & Time of existence & Total duration of existence \\
\hline Spatial characteristics & $\begin{array}{l}\text { Area of territories re-associated at } \\
\text { different dates, area of ATU at dif- } \\
\text { ferent dates }\end{array}$ & $\begin{array}{l}\text { Parameter of temporality of spatial } \\
\text { time }\end{array}$ \\
\hline Name (individual attribute) & Date of change of name & $\begin{array}{l}\text { Number of dates when the name was } \\
\text { changed }\end{array}$ \\
\hline $\begin{array}{l}\text { Type (special attribute for } \\
\text { many ATUs) }\end{array}$ & $\begin{array}{l}\text { Time period, over which the ATU } \\
\text { had the corresponding area }\end{array}$ & $\begin{array}{l}\text { Number of dates when the type was } \\
\text { changed }\end{array}$ \\
\hline
\end{tabular}

Individual qualitative characteristics are hard to demonstrate on a timeline without overloading the map, therefore it is best to show only the facts of their changes. These qualitative characteristics which are typical simaltaneously for different objects on the map and values which are not large can be depicted using colour or other graphical changes in timeline. Variants of the timelines, which we developed for demonstrating the course of changes in an ATD are presented in Fig 2 and Fig 3.

Therefore, for the territory within an ATU for a date of reference (current condition), one can reflect the percentage of the entire territory occupied by a corresponding ATU in different periods of time. For example, Novomoskovsk District in some years covered only a half of its modern day territory. Also an interesting fact is that a part of dynamic ATU in different time instances was lo- cated within its current contour. For CHAB polygons, a diagram can be developed, demonstrating division of number of re-associations over time or in timelines of belonging to a certain ATU (ATUs). However, taking into account peculiarities of sizes of such polygons, using such diagrams is not always possible for maps with large territorial coverage. By contrast, it is often possible and useful for studying small territories, for exam-ple, within several administrative districts. The timeline of belonging of territories in such case allows demonstration of the temporal peculiarities of formation of the territories of these areas and re-association of the territories between them. At the same time, the territory of "historical kernel" can be avoided, so the map focuses on the territories which changed their administrative belonging.

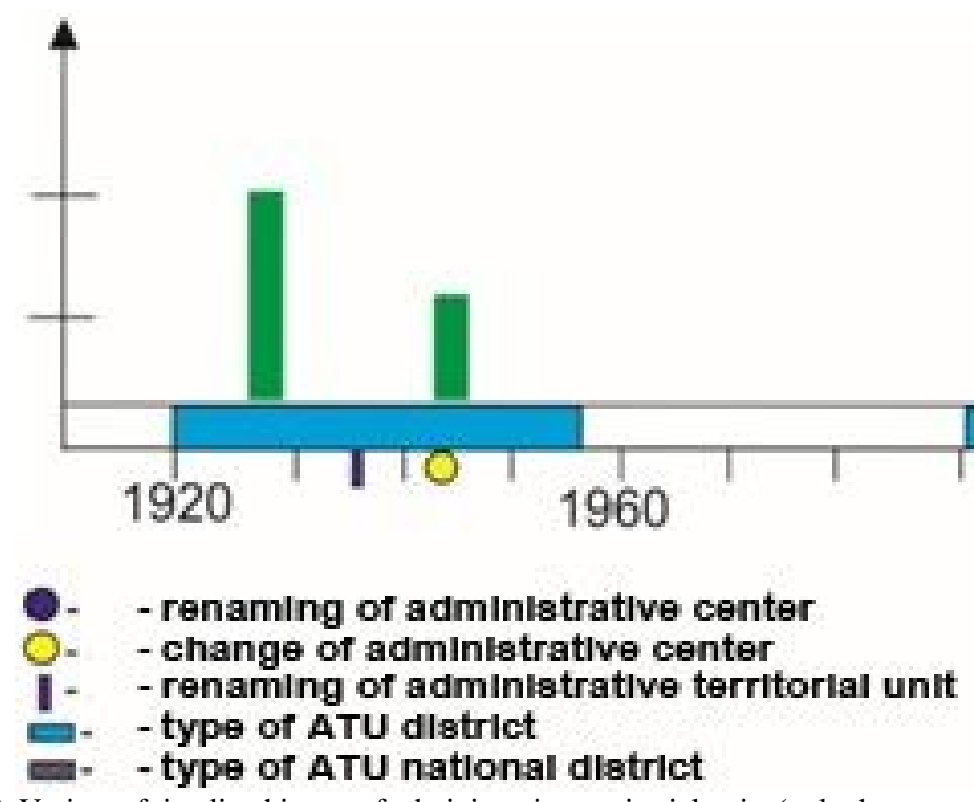

Fig. 2. Variant of timeline history of administrative-territorial units (only the re-associated area is demonstrated). 


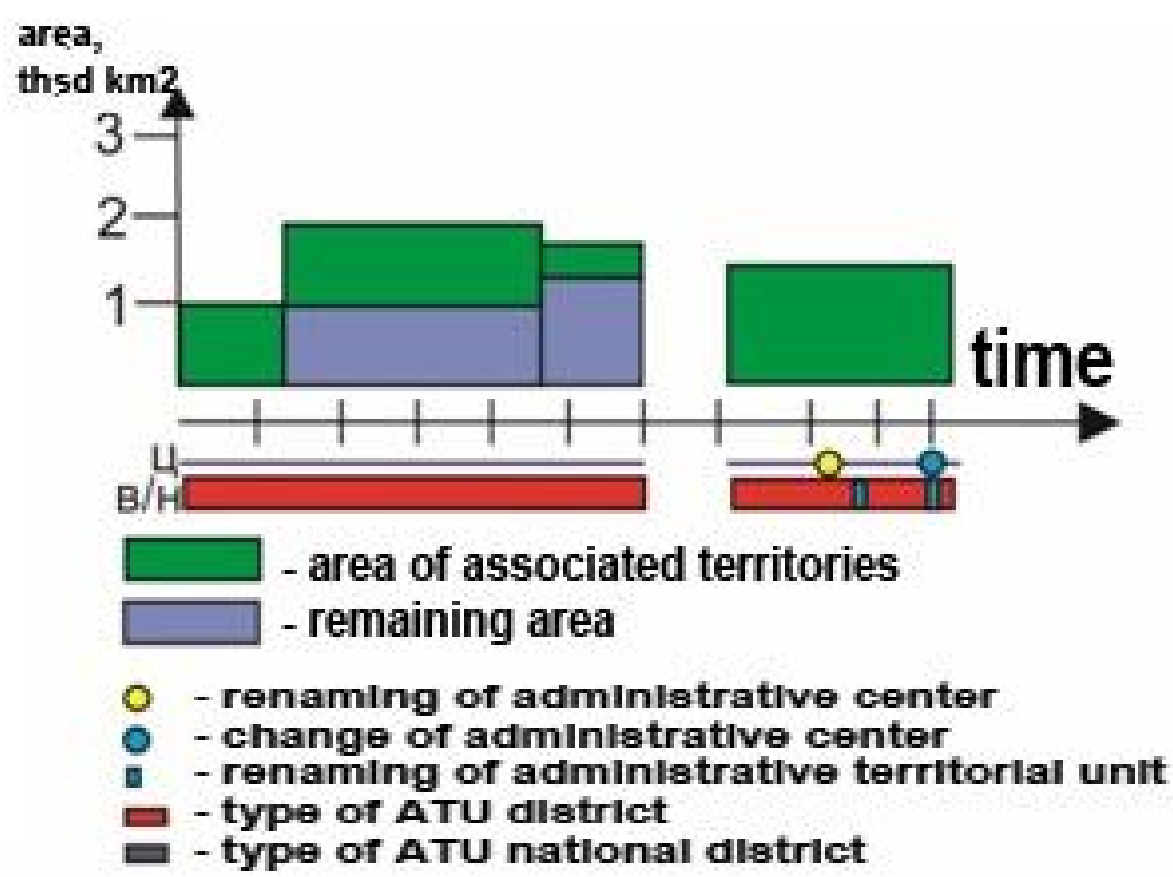

Fig. 3. Variant of timeline of history of administrative-territorial unit (demonstrates the area of associated territories and the area remaining after the change)

In some cases, diagrams of changes in time can be used for static objects which were analyzed above.

The diagrams described above cannot be developed using standard methods of available software, therefore we developed a program of our own, for MapInfo platform for developing maps with such diagrams. They form on separate layers out of spatial objects. Base objects are key points indicators of change, latitude of which corresponds to the latitude of the ATU centroid, and coordinates of longitude are determined as $\mathrm{X} 0+\mathrm{X}$, where $\mathrm{X} 0$ longitude of the initial (last on the left) point on the timeline, $\mathrm{X}-$ shift to the right, calculated as dif- ference between temporal value of the initial point and temporal value of the current point, converted to distance by longitude (Table 3 ). It should be mentioned that for large territories and particular projections, one might need to take into account peculiarities of projection in calculating the longitude of point objects on the timeline.

The size of the time scale for objects on the map is determined by minimum initial date and maximum final date among objects depicted on the map

Table 3. Calculation of longitude of point object-mark about event on the timeline of object

\begin{tabular}{|c|c|c|c|c|c|}
\hline $\begin{array}{c}\text { Date } \\
(\mathrm{d})\end{array}$ & $\begin{array}{c}\text { Longitude of } \\
\text { ATU centroid }\end{array}$ & $\begin{array}{c}\text { Longitude of the } \\
\text { beginning of } \\
\text { timeline scale } \\
\left(\mathrm{X}_{0}\right)\end{array}$ & $\begin{array}{c}\text { Shift of date, } \\
\text { years }\end{array}$ & $\begin{array}{c}\text { Shift of cor- } \\
\text { responding } \\
\text { point ( X) }\end{array}$ & $\begin{array}{c}\text { Longitude of } \\
\text { point on timeline }\end{array}$ \\
\hline $\begin{array}{c}\text { (From the } \\
\text { obtained } \\
\text { table })\end{array}$ & $\begin{array}{c}\text { Is determined } \\
\text { using the function } \\
\text { CentroidX(obj) }\end{array}$ & $\begin{array}{c}\text { CentroidX(obj)- } \\
\mathrm{dX}\end{array}$ & $\mathrm{d}-\mathrm{min}$ & $(\mathrm{d}-\mathrm{min}) * \mathrm{M}$ & $\mathrm{X}_{0}+\mathrm{X}$ \\
\hline
\end{tabular}

min - minimum initial date among all objects depicted on the map, rounded off to a lower value which would be divisible by 10

$\mathrm{M}$ - coefficient of converting the difference in time into the difference in longitude on graph (scale of timeline)

max - maximum final date among all objects depicted on the map, rounded off to a lower value which would be divisible by 10

$\mathrm{dX}=0.5((\max -\mathrm{min}) * \mathrm{M})-$ shift of longitude of beginning of timeline scale from the longitude of centroid of the object to the west for correspondence of longitude of the scale middle with longitude of centroid

Key point objects which demonstrate creation and removal of objects should be connected with lines. If needed, sign points which demonstrate change of a certain parameter are indicated on particular positions on the timeline of the object on a separate layer. These point objects have one 
attribute - value of the studied characteristic for period which follows the date of change. That is, the basic variant of diagram is a shortened variant which does not include depiction of the characteristics, and contains only signs indicating their changes. The exception is the type of ATU which is demonstrated using colours of sections on the timeline. If needed, on the basis of signs indicating changes, which are point objects with corresponding attribute, the value of the attribute is demonstrated using standard tools of MapInfo. For example, above sign points of change in area, bar charts could be developed, and the toponyms would be demonstrated near the sign points indicating change of the name.

It should be mentioned that timelines - diagrams of division of time of existence and changes of objects over time are not very convenient for comparing the objects between one another by total parameters, for example total time of existence or total number of changes, though such parameters can be calculated using the map. To compare the dynamic of an ATU, it is better to use maps which demonstrate the total number of changes over the time period using bar diagrams.

We have automated the development of such maps by writing programs in Mapbasic language. Data for such diagrams are prepared using SQLrequests to the initial data base. Total duration of a ATU's existence is calculated as a sum of differences between final and initial date of all tuples which describe changes in ATU in the main table. Mean area over time is calculated using standard function SQL "wAvr", arguments of the function are differences between initial and final dates, and area of object on these dates, determined using "Area" function. Total number of dates of changes is calculated using SQL-request as (Count-1) with grouping by code of object. Diagrams are developed on the basis of sample available in MapInfo.

Conclusions. As a result of generalisation of data on ATU history over different periods, it is possible to see spatial and spatio-temp,oral division of administrative changes. The objects of mapping can be specially selected polygons, all points of which have the same history of administrative belonging, territory of current ATUs or territory of historical ATU at chosen date, and also ATUs as dynamic objects. In the latter case, the indicators of the dynamic are calculated for object variable in time, and depicted in recorded borders. To depict division of spatial administrative changes, it is best to use polygons of common history of administrative belonging. For such polygons, a general number of changes can be developed, indicating changes of administrative belonging or duration of administrative belonging to a particular ATU. For territories larger than these polygons, it is recommended to use other parameter of temporality of administrative belonging, which is calculated as a ratio between sum of products of multiplying areas of such polygons within the borders by number of reassociations $\left(\mathrm{p}_{\mathrm{i}}\right)$ they underwent to the general area of the territory. There was also developed a similar parameter for an ATU as a temporal object, it includes changes in the area of the analyzed object over time. For ATUs as dynamic objects, apart from the number of changes, it is practical to demonstrate their division over time using special diagrams and timelines.

\section{References}

Berman, Merrick Lex. 2005. Boundaries or networks in historical GIS: Concepts of measuring space and administrative geography in Chinese history. Historical Geography. 118-133.

Berman, Merrick Lex. 2009. Modeling and Visualizing Historical GIS Data. Retrieved from http://www.fas.harvard.edu/ chgis/work/docs/ papers/CGA_Wkshp2009_Lex_9apr09.pdf

DeMoor, M., \& Wiedemann, T. 2001. Reconstructing territorial units and hierarchies: an example from Belgium. History and Computing, 13, 71-97.

Gregory, I.N. 2002. A Place in History: A Guide to Using GIS in Historical Research. Oxford

Gregory, I. 2002. Time-variant GIS databases of changing historical administrative boundaries: a European comparison. Transactions in GIS, 6(2), 161-178. DOI: 10.1111/1467-9671.00103

Gregory, I. 2002. The accuracy of areal interpolation techniques: standardising 19th and 20th century census data to allow long-term comparisons. Computers, Environment and Urban Systems, 26(4), 293-314. DOI: 10.1016/S01989715(01)00013-8

Havriushyn, O. 2018. Uzahalnennia riznochasovykh danykh $\mathrm{z}$ istorii administratyvno-terytorialnoho podilu zasobamy HIS [Generalization of different-time data on the history of administrative-territorial division in GIS]. Inzhenerna heodeziia - Engineering geodesy, 65, 150-158 [in Ukrainian] Retrievedfrom http://geojournal.xyz/docu-ments/65_journal.pdf

Nüssli, M.-A. and Nüssli C. (n.d.) From Historical Mapping to Historical Geographical Information System / Nüssli Marc-Antoine, Nüssli Christos. Retrieved from www.euratlas.net/tele/euratlas_HGIS.pdf

Ott, T. and Swiaczny, F. 2001. Time-Integrative Geographic Information Systems: Management and Analysis of Spatio-Temporal Data. Berlin / Heidelberg / New York: Springer

Renolen, A. 1999. Concepts and methods for modelling temporal and spatiotemporal information. Partial fulfilment for the degree "Thesis", NTNU. Retrieved from http://www.emap.no/docs/ThesisAgnarRenolen.pdf 
Trotsenko, O.V. 2008. Doslidzhennia zmin administratyvno-terytorialnoho ustroiu rehionu yak bazovoi skladovoi systemy vtrachenykh heohrafichnykh obiektiv (na prykladi Dnipropetrovskoi oblasti) [Investigation of changes in the administrative-territorial structure of the region as the basic component of the system of lost geographic objects (for example, Dnipropetrovsk region)] Naukovi zapysky
Vinnytskoho pedahohichnoho universytetu Scientific notes of Vinnytsya State Pedagogical University named after Michailo Kotzubynsky. Series: Geography. issue. 17, 25-30 [in Ukrainian]

Vanhaute, E. 2005. The Belgium Historical GIS. Historical Geography, 33, 136-139.

World History Maps \& Timelines | GeaCron Retrieved from http://geacron.com/ 